\title{
ATF7IP Gene
}

National Cancer Institute

\section{Source}

National Cancer Institute. ATF7IP Gene. NCI Thesaurus. Code C119670.

This gene is involved in the regulation of both histone methylation and transcription. 